\title{
A UNIVERSIDADE EM RUIINAS NA REPÚBLICA DOS PROFESSORES
}

\author{
Fernando Jorge Correia de FREITAS*
}

Constituindo-se a Educação numa das mais importantes esferas da vida social, porque essencialmente política, este livro de Hélgio Trindade possui 0 mérito de conduzir-nos ao debate público sobre a Universidade brasileira, ao englobar considerações tanto acadêmicas como políticas no bojo da educação superior.

Num total de 16 artigos que compõem a obra, os autores dão-nos a possibilidade de perscrutar suas vivências e experiências de gestão administrativa, reservando ao leitor o papel de interlocutor político e, ao mesmo tempo, convocando-o a uma permanente reflexão sobre os destinos ou desmandos da educação superior pública no Brasil, marcada pela diversidade dos discursos políticos que a produziram e constituíram.

Assim, da densidade das análises efetuadas sobre a Universidade, vislumbram-se os processos históricos que levaram à implementação sorrateira do atual modelo e, sob a forma de conceitos, percebem-se aspectos relevantes de acordo com várias interpretações, na medida em que outras análises divergentes ou aproximadas a modelos universitários existentes na América Latina, França, Inglaterra e Estados Unidos são levadas a avaliações.

Contudo, a discussão não se esgota por aí. Na contínua reflexão a que a obra nos induz, percebe-se o esfacelamento da retórica do poder universitário brasileiro, isto é, a dos intelectuais que fazem parte da elite dominante, face às influências histórico-políticas que forçaram a constituição de altemativas de "caráter único", e que gravaram os modelos para a educação superior brasileira.

Devidamente articulados entre si, os artigos orientam-nos no que devem ser considerados pressupostos e fundamentos educacionais: formação, crítica, reflexão e inovação, aliadas inseparáveis da docência e pesquisa. Conseqüentemente, estabelecem critérios definitivos ao questionarem a ideologia neoliberal, que vê a Educação como mais uma mercadoria desvinculada do campo político e também do social, sob o rótulo de "prestação de serviços não exclusivos do Estado".

A clareza implícita nos argumentos dos autores manifesta-se nos objetivos da educação atual, ou seja, na sua missão de preparar o estudante para 0 mundo do trabalho, destinando à pesquisa a sua adequação às necessidades

* Graduado em Ciências Sociais, Especialista em Ciência Política, Mestrando em Educação - PUCPR 
empresariais, numa "qualificação" que obedece a uma visão reducionista de domínio da informática e de linguagem virtual. Por outro lado, compete a este tipo de educação expressar a ideologia dominante e, finalmente, tomá-la um mercado de consumo dos produtos de informática e da indústria cultural.

Estes aspectos, cada vez mais pertinentes, refletem-se nas seguintes questões arquitetadas pelo livro:

- a hegemonia do sistema privado de educação superior, que assume características de empresa educacional, sobre o sistema público estadual e federal;

- a do princípio de autonomia universitária e as novas relações entre o Estado, a Universidade e o seu financiamento;

- a retórica da intelectualidade ao considerar a educação superior como mera prestação de serviços e, como tal, a ser paga, o que exclui uma parcela considerável de atuais e futuros estudantes;

- a ameaça que paira sobre a gratuidade do ensino público superior;

- a avaliação, segundo a lógica do mercado, isto é, de custo-benefício;

- a desvalorização do ensino frente à preponderância da pesquisa ao sabor dos interesses do mercado;

- a ameaça que paira sobre a gratuidade do ensino público superior;

- a avaliação segundo a lógica do mercado, isto é, de custo-benefício;

- a desvalorização do ensino frente à preponderância da pesquisa ao sabor dos interesses do mercado;

- a fragmentação do conhecimento e a hierarquização da Universidade de pesquisa;

- o controle de organismos financeiros internacionais sobre as despesas públicas, no sentido de contê-las, e de moldar a educação a um novo tipo de Estado;

- o paradoxo de alternativas como as da Unesco, ao propor o compromisso do Estado com a educação, considerando-a estratégia de longo prazo e, ao mesmo tempo, a falta de investimentos.

Das contradições entre o discurso e a prática e dos seus efeitos em relação à educação superior, fica evidenciado um projeto político do qual faz parte 0 nosso país. Um projeto por excelência tecnicista, compromissado com 0 mundo "globalizado" e sem ressalvas, sob eufemismos "modernos", como "dinâmico", "flexível", e de "qualidade", que descaracterizam a educçõ pública e, assim, a política sobre a Universidade.

Recebido em 27/5/01 Aprovado em 19/6/01 